Karol Kuźmicz

\title{
Stosunek Czesława Znamierowskiego do filozofii Immanuela Kanta
}

\begin{abstract}
Summary
Czesław Znamierowski (1888-1967) is an author of an original theory of law, in which he developed the concept of social phenomena. He was analyzing the ways of constructing and reasoning of moral and legal norms. His works play important role in the development of Polish philosophy of law. Czesław Znamierowski represented critical approach to German Idealism. However you can find links between his views and Kant's practical philosophy and especially Kant's deontological ethics. In this context you can point relations between Znamierowski's concept of common goodwill and Kant's practical imperative.
\end{abstract}

\section{Wprowadzenie}

Czesław Znamierowski(1888-1967) jestjednym z najwybitniejszych polskich myślicieli. Jego działalność naukowa przypadła na okres Polski międzywojennej oraz ponad 20 lat Polski Ludowej. Uczony ten przyczynił się do rozwoju filozofii prawa. Był „osamotniony w swej oryginalnej próbie stworzenia apriorycznej teorii prawa", którą nawet dzisiaj trudno zaklasyfikować do jakiejkolwiek ze znanych szkół w prawoznawstwie ${ }^{1}$. Potwierdzał to także Adam Łopatka, który pisał o Cz. Znamierowskim jako prawniku żyjącym na przełomie trzech epok

${ }^{1}$ K. Opałek, W. Wolter, Nauka filozofii prawa i prawa karnego w Polsce, Kraków 1948, s. 11; K. Pol, Poczet prawników polskich, Warszawa 2000, s. 1199. 
(tradycyjnej, marksistowskiej i konserwatywnej) i do żadnej w zasadzie nie należał ${ }^{2}$. Niemniej jednak uznaje się go najczęściej za pozytywistę, który określił swoje stanowisko mianem realizmu. Realizm charakteryzuje się według Marii Szyszkowskiej przede wszystkim walką z pozornymi zagadnieniami i pustymi nazwami ${ }^{3}$. Z kolei Stanisław Czepita jego poglądy filozoficznoprawne zalicza do teorii typu socjologicznego, w których „prawo ujmowane jest jako szczególnego rodzaju środek oddziaływania na ludzkie zachowania oraz kształtowania struktur grup społecznych"4.

Na poglądy Cz. Znamierowskiego wpłynęło wiele różnorodnych szkół i kierunków filozoficznych ${ }^{5}$. Większość z nich poddawał ostrej krytyce. Bronił i cenił swoją niezależność tak bardzo, iż często wchodził w konflikty $\mathrm{z}$ otaczającą go rzeczywistością. Żadna partia, czy koteria nie uznała go nigdy za „swojego człowieka"'. Szczególnie ostro wypowiadał się na temat klasycznej filozofii niemieckiej, a zwłaszcza idealizmu - odmawiając mu wartości naukowej, uznając filozofię powstającą po Kancie i Heglu za dekadencką7. Według niego „filozofia Kanta była raczej uwstecznieniem, niż krokiem naprzód" w dziejach filozofii, a idealizm, który wziął z niego początek stanowił „najciemniejszą uliczkę myśli ludzkiej”". Cz. Znamierowski nie zgadzał się więc w tej kwestii z wybitnym polskim historykiem filozofii Władysławem Tatarkiewiczem, uważającym właśnie idealizm niemiecki za okres największego „rozbudzenia” myśli w Niemczech, a epokę Oświecenia za czas, w którym „sztandar filozofii nie był noszony wyżej”. Natomiast Cz. Znamierowski pisał, że „był to okres największej ciemności, zawikłania i zakłamania myśli" ${ }^{10}$. Konsekwentnie był on także wnikliwym krytykiem spekulatywnej filozofii prawa, opartej na idealistycznej filozofii

\footnotetext{
${ }^{2}$ Por. P. Ambroziewicz, Prawnik trzech epok. Rozmowa z prof. dr hab. A. Łopatką, „Prawo i Życie” 1988, nr 22, s. 10.

${ }^{3}$ Por. M. Szyszkowska, Filozofia prawa i filozofia człowieka, Warszawa 1989, s. 98 i n.; eadem, Teorie prawa natury XX wieku w Polsce, Warszawa 1982, s. 80 i n.; zob. Cz. Znamierowski, Realizm w teorii prawa, Poznań 1925, s. 3.

${ }^{4}$ S. Czepita, Koncepcje teoretycznoprawne w Polsce międzywojennej, „Czasopismo Prawno-Historyczne" 1980 , t. 32, z. 2, s. 119.

${ }^{5}$ Idem, Koncepcje teoretycznoprawne Czesława Znamierowskiego, Poznań 1988, s. 15.

${ }^{6} \mathrm{~K}$. Znamierowski, Wspomnienie o Ojcu, [w:] Cz. Znamierowski, Elita, ustrój, demokracja. Pisma wybrane, Biblioteka Polityczna ALTHEIA, t. 12, P. Śpiewak (red.), Warszawa 2001, s. 238.

${ }^{7}$ S. Czepita, Koncepcje teoretycznoprawne Czesława, op. cit., s. 157 i n.; zob. Cz. Znamierowski, Recenzja pracy E. Jarry: Historia filozofii prawa, „Ruch Prawniczy i Ekonomiczny” 1924, nr 3, s. 396; idem, Głos w „Naradach nad teoria prawa”, [w:] Prace z dziedziny teorii prawa, W. L. Jaworski (red.), „Czasopismo Prawnicze i Ekonomiczne” 1925, t. 33, s. 79.

${ }^{8}$ Idem, Historia filozofii praktycznej. cz. 2. Filozofia nowożytna, Poznań 1948, s. 32.

${ }^{9}$ W. Tatarkiewicz, Historia filozofii. Filozofia nowożytna do roku 1830, t. 2, s. 195-197.

${ }^{10} \mathrm{Cz}$. Znamierowski, Historia filozofii, op. cit., s. 32 .
} 
niemieckiej, którą „tępił ze znaną ostrością krytycznego pióra”"11. Bez wątpienia Cz. Znamierowski odznaczał się przenikliwością, jasnością i precyzją słowa połączonego $\mathrm{z}$ dużym polotem i elegancją swoich wypowiedzi ${ }^{12}$.

Ponieważbyłon przedewszystkim „filozofem oszerokimkręgu zainteresowań, wielostronnym wykształceniu i erudycji", to do badań prawniczych przystępował już „nie jako pokorny czeladnik, wiernie podporządkowujący się paradygmatowi zaakceptowanemu przez mistrzów, lecz jako człowiek naukowo dojrzały i zdolny do wnikliwego krytycyzmu"13. Podejście to odpowiadało kantowskiemu wzorcowi filozofowania, który był z założenia właśnie krytycyzmem. Jak zauważył na początku XX w. P. Chmielowski, „kto chce być filozofem w prawdziwym tego słowa znaczeniu" - a takim bez wątpienia chciał być Cz. Znamierowski - „koniecznie z Kantem, i to na serio policzyć się musi”, gdyż cała współczesna filozofia jest jakoby komentarzem do niego, a bez niego staje się bezużyteczna ${ }^{14}$. Znamierowski odnosił się krytycznie do wszystkich koncepcji, które zmierzały do wyeliminowania z zakresu zainteresowań teoretycznoprawnych problemów społecznego funkcjonowania prawa oraz do tych, które nie dostrzegały doniosłości problematyki zaliczanej do tzw. „płaszczyzny logiczno-językowej”" W tym miejscu należy wymienić koncepcję normatywistyczną Hansa Kelsena, czy psychologiczną teorię prawa Leona Petrażyckiego i jej wątki w poglądach Georga Jellinka i Leona Duguita. Krytycznie odnosił się on także do neokantystów, by wymienić Rudolfa Stammlera, Paula Janeta i Gorgio del Vecchio ${ }^{16}$.

${ }^{11}$ Z. Ziembiński, Czesław Znamierowski (1888-1967), „Państwo i Prawo” 1967, R. XXII, z. 12, s. 1019.

${ }^{12}$ Por. Z. Jackiewicz, Nauczyciel prawnego abecadła, „Prawo i Życie” 1987, nr 37, s. 11.

${ }^{13}$ Z. Ziembiński, Czesław Znamierowski, op. cit., s. 1019.

${ }^{14}$ P. Chmielowski, Kant w Polsce, „Przegląd Filozoficzny” 1904, R. VII, z. 4, s. 380 i 391.

${ }^{15}$ S. Czepita, Koncepcje teoretycznoprawne Czesława, op. cit., s. 155 i n.

${ }^{16}$ Zob. Cz. Znamierowski, Recenzja pracy H. Kelsena: Der sociologische und der juristische Staatsbegriff, „Ruch Prawniczy i Ekonomiczny” 1923, nr 1, s. 63-67; idem, Recenzja pracy H. Kelsena: Czysta teoria prawa, „Ruch Prawniczy, Ekonomiczny i Socjologiczny” 1935, nr 1, s. 4-7; idem, Recenzja pracy R. Sammlera: Lehrbuch der Rechtsphilosophie, „Ruch Prawniczy i Ekonomiczny” 1923, nr 3, s. 429-432; idem, Recenzja pracy E. Baturo: Prawne poczucie jako przejaw i forma podświadomego, skrótowego myślenia, „Ruch Prawniczy, Ekonomiczny” 1926, nr 3, s. 492-494; idem, Recenzja pracy E. Baturo: Studia i krytyki z dziedziny teorii i filozofii prawa, „Ruch Prawniczy i Ekonomiczny” 1926, nr 3; idem, Recenzja pracy E. Jarry: Historia filozofii prawa, „Ruch Prawniczy i Ekonomiczny” 1924, nr 3; idem, Recenzja pracy H. Piętki: Stuszność w teorii i praktyce, „Ruch Prawniczy i Ekonomiczny” 1931, nr 3, s. 580-582; idem, Recenzja pracy H. Piętki: Poglądy filozoficzno-prawne Szymona Starowolskiego, „Ruch Prawniczy i Ekonomiczny” 1926, nr 3; idem, Recenzja pracy Sz. Rundsteina: Zasady teorii prawa, „Ruch Prawniczy i Ekonomiczny" 1924, nr 3, s. 390-395; idem, Recenzja pracy F. Znanieckiego: The Law of Social Psychology, „Ruch Prawniczy i Ekonomiczny” 1925, nr 3; idem, Recenzja pracy F. Znanieckiego: Wstęp do socjologii, „Przegląd Warszawski” 1924, nr 37. 
Jednocześnie, wbrew pogardliwemu nastawieniu do idealistycznej filozofii niemieckiej, niektóre jej nurty, a mianowicie te, które przeciwstawiały się tym idealistycznym systemom, znalazły pozytywny wyraz $\mathrm{w}$ jego koncepcjach ${ }^{17}$. Obok filozofii niemieckiej, kolejnym źródłem inspiracji Cz. Znamierowskiego była szkoła lwowsko-warszawska, reizm Tadeusz Kotarbińskiego ${ }^{18}$ oraz realistyczne koncepcje filozofii angielskiej i amerykańskiej ${ }^{19}$. Z tego chociażby względu czymś niemożliwym wydaje się twierdzenie o inspirującym wpływie kantowskiej filozofii na stanowisko zajmowane przez Cz. Znamierowskiego. A jednak, mimo niechęci i dezaprobaty do tej właśnie filozofii, można wskazać pewne jej elementy widoczne w jego poglądach, do czego nie chciał przyznać się sam uczony. W tym kontekście można powiedzieć, że Cz. Znamierowski przejął od Kanta przede wszystkim krytyczny sposób filozofowania i prowadzenia badań, który stał się elementem charakterystycznym uprawianej przez niego nauki. Dokonał rozrachunku zarówno z idealistyczną filozofią niemiecką, w tym filozofią Kanta, jak również z psychologiczną teorią prawa L. Petrażyckiego ${ }^{20}$. Sformułował także nową, tzn. aprioryczno-dedukcyjną teorię prawa ${ }^{21}$.

\section{Działalność naukowa Czesława Znamierowskiego}

Swoją pracę naukową Cz. Znamierowski rozpoczął przed 1918 r., studiując w różnych krajach. W 1905 r. rozpoczął studia filozoficzne na Uniwersytecie w Lipsku, uczestnicząc m.in. w wykładach W. Wundta ${ }^{22}$. Następnie studiował przez rok filozofię i historię na Uniwersytecie w Petersburgu (1906/1907), by ponownie wrócić do Lipska, gdzie obok kontynuowania studiów z filozofii, zgłębiał także matematykę i fizykę. W 1909 r. wyjechał do Berlina na studia psychologiczne uC. Stumpfa, a rokpóźniej do Monachium na studia socjologiczne, podczas których brał udział $\mathrm{w}$ seminarium filozoficznym $\mathrm{H}$. Corneliusa ${ }^{23}$. W latach 1911-1912 złożył egzaminy doktorskie z filozofii oraz matematyki

${ }^{17}$ Por. S. Czepita, Koncepcje teoretycznoprawne Czesława, op. cit., s. 15.

${ }^{18} \mathrm{Cz}$. Znamierowski miał na myśli Szkice praktyczne Tadeusz Kotarbińskiego, a zwłaszcza teorię działania, która była jego „bodźcem i wzorem”. Zob. Cz. Znamierowski, Podstawowe pojęcia teorii prawa, cz. 2. Prolegomena do nauki o państwie, Warszawa 1934, s. 8; idem, Realizm w teorii prawa, Poznań 1925, s. 3.

${ }^{19}$ Por. S. Czepita, Koncepcje teoretycznoprawne Czesława, op. cit., s. 15.

${ }^{20}$ Zob. Cz. Znamierowski, Recenzja pracy L. Petrażyckiego: Wstęp do nauki prawa i moralności. Podstawy psychologii emocjonalnej, „Ruch Prawniczy, Ekonomiczny i Socjologiczny” 1931, nr 3; idem, Logika a teoria prawa. Replika panu Landemu z powodu recenzji o "Podstawowych pojęciach prawa”, „Czasopismo Prawnicze i Ekonomiczne” 1925, R. XXIII, nr 1-12.

${ }^{21}$ Por. K. Pol, Poczet prawników, op. cit., s. 1202.

${ }^{22}$ S. Czepita, Koncepcje teoretycznoprawne Czesława, op. cit., s. 9 i n.

${ }^{23}$ Por. ibidem, s. 10; K. Pol, Poczet prawników, op. cit., s. 1200. 
i fizyki jako przedmiotów dodatkowych na Uniwersytecie w Bazylei, na którym uzyskał doktorat z filozofii na podstawie rozprawy Wahrheitsbegriff im Pragmatismus (O pojęciu prawdy w pragmatyzmie) ${ }^{24}$. Po odzyskaniu przez Polskę niepodległoś-ci podjął na Wydziale Prawno-Ekonomicznym w Poznaniu studia prawnicze (1919-1922) $)^{25}$ pod kierunkiem Antoniego Peretiatkowicza, o którym we wspomnieniach pisał: „Prof. Antoni Peretiatkowicz pomógł mi decydująco, ukazując możliwość objęcia katedry. Tutaj w Poznaniu, dzięki jego inicjatywie, mogłem się wyzwolić z obowiązków nauczyciela szkół średnich i rozprężyć myśl w szerokich ramach wolności akademickiej. Wykorzystałem ją sumiennie dla pracy naukowej"26. Podobnie jak A. Peretiatkowicz - Cz. Znamierowski związał się z nowo tworzonym Uniwersytetem w Poznaniu, na którym w 1922 r. uzyskał stopień doktora prawa na podstawie dysertacji Psychologiczna teoria prawa. Objął wówczas jako zastępca profesora Katedrę Filozofii i Teorii Prawa, w której po wojnie pod zmienioną nazwą Katedry Teorii Państwa i Prawa przepracował 38 lat $^{27}$. W 1924 r. obronił rozprawę habilitacyjną zatytułowaną Podstawowe pojęcia teorii prawa. Układ prawny $i$ norma prawna. Został docentem teorii i filozofii prawa ${ }^{28}$. Następnie w 1927 r. został profesorem nadzwyczajnym, a w 1934 r. profesorem zwyczajnym na poznańskiej uczelni, od której w 1965 roku otrzymał najwyższą godność akademicką - tytuł doktora honoris causa ${ }^{29}$. W 1916 r. został członkiem Warszawskiego Instytutu Filozoficznego, od 1924 roku należał również do Poznańskiego Towarzystwa Przyjaciół Nauk, a od 1934 roku do Towarzystwa Naukowego Warszawskiego. Od 1938 r. był członkiem prestiżowego Institut International de Philosophie du Droit et de Sociologie Juridique, a po II wojnie światowej, w 1948 r., został członkiem-korespondentem Polskiej Akademii Umiejętności ${ }^{30}$.

$\mathrm{Na}$ odrębną uwagę zasługują epizody związane ze stosunkiem Cz. Znamierowskiego do władz, i to zarówno polskich z okresu przedwojennego, jak i powojennego oraz niemieckich władz okupacyjnych. Jak podaje syn uczonego, Cz. Znamierowski był zwolennikiem Józefa Piłsudskiego, choć nie był nigdy

${ }^{24}$ Z. Ziembiński, Czesław Znamierowski (1888-1967), op. cit., s. 1017-1018.

${ }^{25}$ Por. A. Śródka, Uczeni polscy XIX-XX stulecia, t. 4, Warszawa 1998, s. 610; J. Wąsicki, Znamierowski Czesław, [w:] Wielkopolski Słownik Biograficzny, Warszawa - Poznań 1981, s. 878.

${ }^{26}$ Cyt. za: K. Pol, Poczet prawników, op. cit., s. 1201.

${ }^{27}$ Ibidem, s. 1208.

${ }^{28}$ J. Wąsicki, Znamierowski, op. cit., s. 878; N. Łubnicki, Czesław Znamierowski. Sylwetka uczonego i myśliciela, „Studia Filozoficzne” 1968, nr 2, s. 53; Z. Ziembiński, Czesław Znamierowski 1888-1967, „Ruch Filozoficzny” 1968, t. 26, nr 4, s. 299 i 300.

${ }^{29}$ Uchwałą Senatu Uniwersytetu im. Adama Mickiewicza w Poznaniu z dnia 5 grudnia 1965 r. Profesorowi Cz. Znamierowskiemu nadano tytuł doktora honoris causa, którego uroczysta promocja odbyła się 18 kwietnia $1966 \mathrm{r}$.

${ }^{30}$ K. Pol, Poczet prawników, op. cit., s. 1206. 
związany z sanacją, jak przypisują mu to niektórzy ${ }^{31}$. W swoich pracach uzasadniał przełom majowy, jego źródła duchowe i ideologiczne, oceniając przeobrażenia i czynniki ustrojowe Polski odrodzonej ${ }^{32}$. W okresie okupacji ścigany za działalność antyniemiecką przez gestapo został zmuszony do opuszczenia Poznania i ukrywania się wraz z rodziną w Generalnej Guberni. Do 1940 r. przebywał w Warszawie, później w Kozłówce na Lubelszczyźnie (do 1943 r.), a następnie w Puławach, gdzie w Państwowym Instytucie Nauk Gospodarstwa Wiejskiego kierował Poradnią Psychotechniczną ${ }^{33}$. Do Wielkopolski powrócił już w 1945 r., podejmując ponownie pracę na poznańskim uniwersytecie. Nigdy nie został przez żadną władzę odznaczony jakimkolwiek znaczącym orderem, a w 1961 r. został przeniesiony na przedwczesną emeryturę ${ }^{34}$. Był ograniczany w swojej działalności naukowej przez cenzurę, która przez długi czas nie dopuszczała do wydania m.in. Szkoły prawa. Rozważań o państwie ${ }^{35}$.

Filozofię prawa uprawiał $\mathrm{Cz}$. Znamierowski z podwójnym przygotowaniem, jako filozof i jako prawnik, łącząc oba te kierunki w swoich doskonałych analizach pojęciowych. Tak w okresie dwudziestolecia międzywojennego, jak i po wojnie wniósł „twórczy wkład do prawoznawstwa polskiego i do innych nauk społecznych" ${ }^{36}$. Jak podaje N. Łubnicki, Cz. Znamierowski był określany mianem „tytana pracy”. Słuszne wydaje się użycie tego określenia, bowiem poza kilkunastoma książkami, ponad dwustu rozprawami, artykułami i recenzjami pozostawił także znakomite przekłady fundamentalnych dzieł kultury zachodniej z zakresu historii filozofii, teorii poznania, logiki, psychologii, etyki, filozofii społecznej i prawa ${ }^{37}$. Publikował swoje prace ${ }^{38}$ także w licznych czasopismach:

\footnotetext{
${ }^{31}$ K. Znamierowski, Wspomnienie, op. cit., s. 238; por. A. Śródka, Uczeni Polscy, op. cit., s. 612.

${ }^{32}$ Zob. Cz. Znamierowski, Konstytucja Styczniowa i ordynacja wyborcza, [w:] idem, Elita, ustrój, demokracja, op. cit., s. 145-235.

${ }^{33}$ Por. K. Pol, Poczet prawników, op. cit., s. 1206;

${ }^{34}$ Por. K. Znamierowski, Wspomnienie, op. cit., s. 238.

${ }^{35}$ Zob. Nauka a polityka. Dziwne losy filozofii prawa w Polsce, M. Szyszkowska (red.), Warszawa 2001; I. S. Grat, Filozofia prawa w Polsce po 1989 roku, [w:] Filozofia prawa, M. Szyszkowska (red.), s. 153-162; Filozofia prawa a tworzenie i stosowanie prawa, B. Czech (red.), Katowice 1992.

${ }^{36}$ K. Pol, Poczet prawników, op. cit., s. 1198; por. T. Kotarbiński, Wspomnienie o Czesławie Znamierowskim, „Ruch Filozoficzny” 1968, t. 26, nr 4, s. 297.

${ }^{37}$ N. Łubnicki, Czesław Znamierowski, op. cit., s. 54. Przetłumaczył m.in.: Zasady etyki - T. Morusa (1919), Wstęp do prawoznawstwa (1924) i Zarys filozofii prawa (1938) - G. Radbrucha, Traktat o naturze ludzkiej (1951/52) - D. Hume'a, Lewiatana (1954) i Elementy filozofii (1956) - T. Hobbes'a, Wstęp do filozofii matematyki - B. Russella (1958), Eseje - F. Bacona (1959), System logiki dedukcyjnej i indukcyjnej - J. S. Milla (1962), Historie filozofii - B. Fullera.

${ }^{38}$ Czesław Znamierowskiego napisał m.in.: Realizm $w$ teorii prawa (1925), Prolegomena do nauki o państwie (1930), Wiadomości elementarne o państwie (1930), O naprawie studiów prawniczych (1938), Oceny i normy (1957), Wina i odpowiedzialność (1957), Zasady i kierunki etyki (1957), Rozważania wstępne do nauki o moralności i prawie (1964). Zob. także bibliografię jego prac opublikowaną w „Ruchu Prawniczym i Ekonomicznym" 1963, nr 2.
} 
„Przeglądzie Filozoficznym”, którego był członkiem redakcji od 1922 r., „Ruchu Prawniczym, Ekonomicznym i Socjologicznym", w którym był kierownikiem działu socjologicznego w latach 1925-1937, „Państwie i Prawie”, gdzie był członkiem redakcji w latach 1946-1950, a także "Studiach Filozoficznych", „Czasopiśmie Prawniczym i Ekonomicznym”, „Przeglądzie Współczesnym”, „Przeglądzie Warszawskim”, „Drodze”, „Czasopiśmie Adwokatów Polskich”, „Myśli Współczesnej”, „Ruchu Pedagogicznym” oraz „Życiu Nauki” ${ }^{39}$.

\section{Filozofia prawa wobec problemów stanowienia prawa}

Niemały wpływ na podejście do zagadnień teoretycznoprawnych Cz. Znamierowskiego miała socjologia, której właśnie „teoria prawa jest, a raczej być winna, jednym z działów (...)”, ponieważ jej zadaniem jest nie tyle „(...) badanie samych norm prawnych, czy logicznego związku pomiędzy normami, leczbadanie grupy społecznej jako rządzącej się pewnymi normami postępowania, warunków obowiązywania tych norm, związku pomiędzy faktem obowiązywania norm, a strukturą społeczną itp." ${ }^{30}$. Filozofia prawa, która ma charakter spekulatywny, tak daleko odbiega, jego zdaniem, od podstaw naukowego myślenia i zajmuje stanowisko sprzeczne $\mathrm{z}$ tendencjami nauki, że może być szkodliwa. Nie liczy się ona $\mathrm{z}$ faktami lub je lekceważy, odrywając je od empirycznej podstawy ku apriorycznym, z rozumu najczęściej czystego płynących konstrukcji, dowolności założeń, niejasności myśli i wieloznaczności terminów. Do uprawiania teorii prawa nie jest przygotowany dogmatyk prawa, gdyż brak mu odpowiedniej wiedzy logicznej, która nie tyle ma doskonalić sprawność myślenia, co zapoznawać $\mathrm{z}$ budową systemów dedukcyjnych ${ }^{41}$. Filozofia prawa ma określać ideał, który prawo powinno urzeczywistniać, zaś polityka - wskazywać środki prowadzące do jego urzeczywistnienia ${ }^{42}$. Według Cz. Znamierowskiego ten, kto stanowi normę zawsze czyni to z pewnym celem, ażeby uregulować określone działania. Wyznaczając cel swojej normie - normodawca przedstawia sobie, że jej obowiązywanie będzie faktem, który zajmie pewne określone miejsce w łańcuchu przyczyn i skutków ${ }^{43}$. Stanowienie norm jest „decyzją w ogromnej

\footnotetext{
${ }^{39}$ Por. A. Śródka, Uczeni Polscy, op. cit., s. 611; Czy wiesz kto to jest?, z. 1, S. Łoza (red.), Warszawa 1938, s. 848-849.

${ }^{40} \mathrm{Cz}$. Znamierowski, Po zjeździe filozofów prawa. Uwagi i refleksje, [w:] Prace z dziedziny teorii prawa, W. L. Jaworski (red.), „Czasopismo Prawnicze i Ekonomiczne” 1925, R. XXIII, z. 1-12, s. 350-351.

${ }^{41}$ Por. ibidem, s. 354 i n.

${ }^{42}$ Idem, Podstawowe pojęcia teorii, op. cit., s. 47.

${ }^{43}$ Por. idem, Z rozmyślań teoretyka prawa, „Ruch Prawniczy, Ekonomiczny i Socjologiczny” 1929, R. IX, z. 1, s. 190-191.
} 
większości przypadków opierającą się na uprzedniej ocenie i na powstałym z niej poczuciu powinności aksjologicznej, (...) która wskazuje, co czynić należy, albo co czynić ma się uprawnienie we wszystkich przypadkach danego typu" ${ }^{\prime 4}$. W ten sposób wyznacza ona powinność działania dla określonego przypadku przyszłego, jaki w rozumieniu tego, kto ją stanowi zjawi się na pewno. Jako swoisty akt woli może wyznaczać nie tylko własne działania, lecz również i cudze, co określa się wówczas mianem stanowienia społecznego ${ }^{45}$.

Cz. Znamierowski zaliczał normy prawne, jak wszystkie inne normy, do kategorii zdań, czyli wypowiedzi posiadających określoną wartość logiczną ${ }^{46}$. Wszystkie normy są bowiem szczególnego rodzaju „całościami organicznymi” ${ }^{4}$, które ujmował on jako swoiste rzeczy, odmienne jednak od zlokalizowanych w czasie i przestrzeni brył fizycznych, a więc „całości” nie mających „charakteru aktualnych zjawisk, lecz raczej charakter rzeczy, czegoś co trwa w sposób ciągły i w nieciągłych zjawiskach się tylko częściowo aktualizuje" ${ }^{\prime 4}$. W ten sposób norma, jako pewnego rodzaju „całość organiczna”, była czymś na wzór są-du w sensie logicznym ${ }^{49}$. Jak podaje S. Czepita, „,normą w rozumieniu Cz. Znamierowskiego jest informacja o powinności uzasadnionej czyjąś oceną czy też czyimś aktem stanowienia" ${ }^{50}$. Odróżniając normy aksjologiczne i normy tetyczne uznał, że pierwsze są zdaniami stwierdzającymi powinność określonego postępowania pewnej osoby, ze względu na to, iż postępowanie to jest w czyichś ocenach aprobowane ${ }^{51}$. Natomiast drugie, to $\mathrm{w}$ jego ujęciu zdania stwierdzające także powinność określonego postępowania danej osoby, ale ze względu na zajście swoistego aktu społecznego nazwanego przez Cz. Znamierowskiego właśnie aktem stanowienia $^{52}$. Na tej podstawie normy prawne mogły być tylko normami tetycznymi. Wśród nich wyróżniał on normy konstrukcyjne i koercytywne. Normy konstrukcyjne „wskazują nie to, że ma być wykonane działanie, lecz jak ma być wykonane" 53 , zaś normy koercytywne stwierdzają, że osoba "A" powinna zachować się w określony sposób, w przeciwnym wypadku inna

${ }^{44} \mathrm{Idem}$, Rozważania wstępne do nauki o moralności i państwie, Warszawa 1964, s. 133 i n.

${ }^{45}$ Ibidem, s. 155-158; idem, Społeczne stanowienie norm, „Ruch Prawniczy, Ekonomiczny i Socjologiczny" 1930, z. 1, s. 274-284.

${ }^{46}$ Idem, Podstawowe pojęcia teorii, op. cit., s. 22 i n.

${ }^{47}$ Por. ibidem, s. 47-49; idem, O przedmiocie i fakcie społecznym, „Przegląd Filozoficzny” 1921, nr 1 , s. 20-22.

${ }^{48}$ Ibidem, s. 20.

${ }^{49}$ Por. S. Czepita, Koncepcje teoretycznoprawne Czesława, op. cit., s. 39.

${ }^{50}$ Idem, Koncepcje teoretycznoprawne, op. cit., s. 124.

${ }^{51}$ Ibidem, s. 124; zob. Z. Ziembiński, Normy tetyczne a normy aksjologiczne w koncepcji Cz. Znamierowskiego, „Studia Filozoficzne” 1963, nr 2.

${ }^{52}$ Por. Cz. Znamierowski, Podstawowe pojęcia teorii, op. cit., s. 31-40.

${ }^{53}$ Idem, Oceny i normy, Warszawa 1957, s. 504. 
osoba „B” powinnaspowodowaćnaosobie,A”,któraniewykonałaswegoobowiązku wystąpienie stanu rzeczy „X”, uznawanego za niekorzystny dla niej - osoby "A $\mathrm{A}^{\text {"54. }} \mathrm{W}$ ten sposób normy prawne wchodzą w skład tzw. „układu prawnego" ${ }^{55}$, który jest zespołem norm konstrukcyjnych i koercytywnych obowiązujących w jakiejś grupie społecznej, kształtujących dla większości członków tej grupy, przynajmniej $\mathrm{w}$ pewnym zakresie ich postępowań, sytuację przymusową ${ }^{56}$. A zatem dopiero norma chroniona sankcją staje się normą prawną $a^{57}$, ta zaś by pozostawać w układzie norm winna też być normą konwencjonalną (umowną) i teleologiczną (celowościową) zarazem ${ }^{58}$.

Znamierowski twierdził także, iż o celu normodawcy, który jest tym samym co cel normy, stanowi jego wiedza o prawie natury, skąd płynie poważna trudność przy ustalaniu tego celu $^{59}$. W tym kontekście z filozoficznoprawnego punktu widzenia szczególnie ważne przy omawianiu stanowiska danego autora staje się określenie jego stosunku do prawa natury (naturalnego). Stosunek Cz. Znamierowskiego do tego prawa można powiedzieć, że nie był jednoznaczny, tym bardziej, że w literaturze jest do dziś niejasno interpretowany ${ }^{60}$. Interesujące jest przy tym to, że Cz. Znamierowski używał często terminu prawo natury, określając zarówno zdeterminowane przyczynowo prawa przyrody oraz prawa, u podstaw których leżała wolność. Według niego „zarówno prawa niezmiennego sprzężenia cech, jak

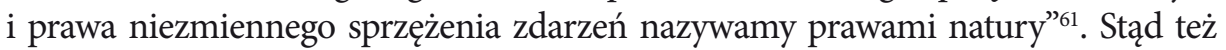
istnieją gatunki tak rozumianych praw natury jako zdeterminowane prawa struktury i prawa przyczynowe. Pierwsze, jak wskazuje ich nazwa, stwierdzają sprzężenie cech, drugie zaś sprzężenie zdarzeń. „Prawa struktury znajdują wyjaśnienie w prawach przyczynowych; prawa przyczynowe wymagają starannego opisu struktury układu, w których zachodzą rozważane zdarzenia sprzężone"62. Z kolei koncepcja praw natury jako praw wolnościowych wynikała $\mathrm{z}$ tezy o istnieniu naturalnych praw człowieka. W odróżnieniu jednak od klasycznych teorii tego prawa zakładających, że jego źródłem może być istota, tj. natura ludzka, Bóg, czy też rozum, Cz. Znamierowski uważał, iż prawa człowieka są „wyrazem raczej natury ocen, tego kto stwierdza

${ }^{54}$ Por. idem, Realizm w teorii, op. cit., s. 21-29; S. Czepita, Koncepcje teoretycznoprawne, op. cit., s. 124.

${ }^{55}$ Cz. Znamierowski, Podstawowe pojęcia teorii, op. cit., s. 177.

${ }^{56}$ S. Czepita, Koncepcje teoretycznoprawne, op. cit., s. 124.

${ }^{57}$ Cz. Znamierowski, Zasady i kierunki etyki, Warszawa 1957, s. 55.

${ }^{58}$ Por. idem, Oceny, op. cit., s. 504 i n.

${ }^{59}$ Por. idem, Z rozmyślań teoretyka, op. cit., s. 190-191.

${ }^{60}$ Por. Z. Ziembiński, Koncepcje filozoficzne Czesława Znamierowskiego, „Ruch Filozoficzny” 1970, nr 1-2, s. 11.

${ }^{61}$ Cz. Znamierowski, Oceny, op. cit., s. 54.

${ }^{62}$ Ibidem, s. 54. 
ich istnienie, niż samej natury człowieka w ogóle"63. Odróżnienie praw natury jako praw zdeterminowanej przyrody oraz praw wolnościowych związanych z człowiekiem jako istotą rozumną, wolną i moralną odpowiada założeniom kantowskiej filozofii, która zakłada przecież, że człowiek należy jednocześnie do dwóch światów: zjawisk (fenomenów) i wolności, czy też noumenów. Przy czym pojęcie przyczynowości przyrody nie odnosi się do „świata noumenalnego”. W nim dochodzi do głosu wolność woli podlegająca moralności ${ }^{64}$.

\section{Naczelna norma moralna według Czesława Znamierowskiego}

Zastanawiając się nad znaczeniem teorii prawa natury, Cz. Znamierowski doszedł do wniosku, iż prawo to odegrało ważną i pożyteczną rolę w kształtowaniu ustroju demokratycznego, stanowiąc wzór dla prawa pozytywnego oraz zaporę dla roszczeń despotyzmu ${ }^{65}$. Według M. Szyszkowskiej wyróżnił on dwa rodzaje norm określanych mianem prawa natury: pierwsze, normy instrumentalne służące głównie zachowaniu równowagi $\mathrm{w}$ zbiorowościach i grupach oraz ich integralności ${ }^{66}$, drugie, normy moralne, które uważał za poczęte $\mathrm{z}$ ocen dotyczących pozycji jednostek w zbiorowości czy też grupie ${ }^{67}$. W powyższym kontekście normy prawa, które z kolei ustalają uprawnienia przyrodzone, nie są prawami natury $w$ znaczeniu opisowym, czy przyrodniczym; nie są one prawami bezwzględnymi, lecz są jedynie dyrektywami, opartymi o życzliwość powszechną ${ }^{68}$. Życzliwość powszechna stanowi jedyną naczelną normę, która wyznacza, że „każdy człowiek powinien być życzliwy powszechnie i życzliwością tą powinien się kierować w każdym swym akcie woli, już to jako pozytywnym impulsem do działania, już to jako impulsem, powściągającym inne działania”' ${ }^{\prime 9}$. Dodatkowo naczelna norma w koncepcji Cz. Znamierowskiego rozszczepia się na cztery, niezależne od siebie, normy składowe określające, co człowiek życzliwy powszechnie winien czynić, a czego winien zaniechać: „Każdy człowiek winien w granicach swej możności po pierwsze, powstrzymywać się od wszelkiego

${ }^{63}$ Idem, Wiadomości elementarne o państwie, Warszawa 1934, s. 84 i n.

${ }^{64}$ Por. I. Kant, Krytyka praktycznego rozumu, tłum. J. Gałecki, Warszawa 1972, s. 155 i n.; idem, Metafizyczne podstawy nauki o cnocie, tłum. W. Galewicz, Kęty 2005, s. 126; idem, Uzasadnienie metafizyki moralności, tłum. M. Wartenberg, Warszawa 1984, s. 86 i n.

${ }^{65}$ Cz. Znamierowski, Wiadomości elementarne, op. cit., s. 85.

${ }^{66}$ Por. M. Szyszkowska, Filozofia prawa i filozofia, op. cit., s. 99-100; eadem, Teorie prawa natury $X X$ wieku, op. cit., s. 82.

${ }^{67}$ Por. Cz. Znamierowski, $Z$ abecadła prawoznawcy, „Ruch Prawniczy i Ekonomiczny” 1958, nr 1, s. $131-132$.

${ }^{68}$ Ibidem, s. 133.

${ }^{69} \mathrm{Idem}$, Rozważania wstępne do nauki, op. cit., s. 48-49. 
działania, które przyczynia komuś cierpienia; po drugie, winien czynnie zmniejszać sumę cierpień innych ludzi; po trzecie, powinien powstrzymywać się od wszelkiego działania, które nie pozwala powstawać cudzym radościom; po czwarte wreszcie, winien czynnie zwiększać sumę zadowolenia wszystkich ludzi"70. Pierwsze dwie dotyczą postawy człowieka wobec cudzego cierpienia, dwie drugie - postawy wobec cudzej radości. Przy czym pierwsza i trzecia nakazują postawę zaniechania, a druga i czwarta postawę aktywną. Na tej podstawie naczelną normę moralną, którą wyraża życzliwość powszechna, można uznać, z punktu widzenia jej funkcji, za pewnego rodzaju odpowiednik podstawowej zasady prawa natury, jak twierdzi M. Szyszkowska ${ }^{71}$. Z kolei Z. Jackiewicz podkreśla, że etyka Cz. Znamierowskiego kładzie wyraźny akcent na nierówny rozdział powinności moralnej, która sięga tak daleko, jak daleko sięga moc każdego człowieka zależna od jego wiedzy, pozycji społecznej, majątku, cielesnej i psychicznej energii ${ }^{72}$. Od ludzi słabszych wymaga się zatem mniej niż od silnych. W ten sposób słabsi, jako pasywni, powinni respektować przykazanie pierwsze i trzecie, a silni, jako aktywni, drugie i czwarte.

Życzliwość powszechna troszczy się zatem o dobro wszystkich ludzi w równym stopniu i dezaprobuje czyny, które nie liczą się z innymi ludźmi i czynią komukolwiek krzywdę ${ }^{73}$. Zdaniem Cz. Znamierowskiego, można ją jedynie żywić do osób lub istot żywych ${ }^{74}$. Życzliwość może być skierowana ku określonej jednostce - wtedy jest indywidualna, natomiast gdy ujawnia się wielu osobom, ale każdej z osobna, jest generalna. „Życzliwość powszechna jest najbardziej pewną i niezawodną podstawą uspołecznienia; kto ją żywi, ten najprawdopodobniej liczyć się będzie z innymi ludźmi, wczuwać w ich przeżycia i wspierać ich swoją pomocą"75. A zatem życzliwość powszechna, która dąży do największego dla wszystkich przydziału szczęścia, musi być świadoma tego, iż jej przedmiotem jest każdy człowiek, gdziekolwiek by się znajdował ${ }^{76}$. Celem tak rozumianej życzliwości powszechnej jest jednoczesne dążenie do szczęścia i do doskonałości. Dążenia te nie pozostają ze sobą w zasadniczym konflikcie, stanowiąc dwie postacie miłości własnego „ja”. „Doskonałość daje zadowolenie i jest trwałym źródłem zadowolenia, a więc pozycją ważną $\mathrm{w}$ przychodzie

${ }^{70}$ Ibidem, s. 50 .

${ }^{71}$ M. Szyszkowska, Europejska filozofia prawa, Warszawa 1993, s. 145; eadem, Filozofia prawa i filozofia, op. cit., s. 99; eadem, Teorie prawa natury XX wieku, op. cit., s. 81-82.

${ }^{72}$ Z. Jackiewicz, Cztery przykazania życzliwości powszechnej, „Prawo i Życie” 1992, nr 42, s. 10.

${ }^{73} \mathrm{Cz}$. Znamierowski, Etyka znów normatywna, [w:] Charisteria. Rozprawy filozoficzne złożone $w$ darze Władysławowi Tatarkiewiczowi w siedemdziesiąta rocznicę urodzin, Warszawa 1960, s. 312.

${ }^{74}$ Idem, Oceny, op. cit., s. 318.

${ }^{75}$ Idem, Rozważania wstępne do nauki, op. cit., s. 34.

${ }^{76}$ Por. ibidem, s. 32 i n. 
szczęścia"77. Odpowiada to kantowskiej nauce o cnocie, zgodnie z którą własna szczęśliwość jest wprawdzie celem, ale nie może być obowiązkiem wszystkich ludzi ${ }^{78}$. Na pytanie, jakie cele są zarazem obowiązkami, Kant odpowiedział, że są nimi własna doskonałość (moralna) i szczęście innych ${ }^{79}$. W powyższym kontekście życzliwość według niego jest synonimem życzenia innym dobra, czyli zadowoleniem ze szczęścia innych ${ }^{80}$. Zgodnie bowiem z etycznym nakazem doskonałości, miłość bliźniego oraz maksyma życzliwości, jako praktyczna miłość do ludzi, ,jest obowiązkiem wszystkich ludzi w stosunku do siebie nawzajem, bez względu na to, czy uważa ich się godnych miłości, czy też nie"s1.

Życzliwość powszechna stanowi także źródło sprawiedliwości moralnej i społecznej. Jest ona sprawiedliwa ze swej istoty, ponieważ „w swoim przydziale troski o dobro ludzi: pragnie w równej mierze ich szczęścia" ${ }^{22}$. Toteż człowiek życzliwy powszechnie, czyli dobry - jest tym samym sprawiedliwy. Słuszne więc było odwieczne, intuicyjne, choć niejasne poczucie, że „sprawiedliwość moralna i społeczna ściśle się wiąże $z$ dobrocią"83. Sprawiedliwość jako najwyższa i naczelna cnota jest poczuciem związanym „Z równym przydzielaniem czy z równym rozdziałem czegos"s" ${ }^{4}$. Zgodnie z życzliwością powszechną, każdy człowiek powinien darzyć każdego innego człowieka równą miarą życzliwości. W powyższym kontekście życzliwość powszechna pilnuje i czujnie baczy na to, czy ludzie sprawiedliwie dzielą między sobą swoje uczucia i pragnienia, ale także inne dobra, które dają warunki szczęścia ${ }^{85}$. Dlatego człowiek życzliwy powszechnie, który jest wrażliwy na krzywdę innych ludzi, dąży, zdaniem Cz. Znamierowskiego, do sprawiedliwości społecznej, czyli równego przydziału szczęścia dla każdego. Dążenie to jest przy tym jedynym czynnikiem, który rozmyślnie i planowo może prowadzić do twórczych i pozytywnych przeobrażeń społecznych, w tym ustrojowych ${ }^{86}$. Według niego z życzliwością powszechną, najbardziej ze wszystkich form ustrojowych, wiąże się idea demokracji ${ }^{87}$. Być zwolennikiem ustroju demokratycznego, to być powodowanym życzliwością

${ }^{77}$ Idem, Oceny, op. cit., s. 301-302.

${ }^{78}$ Por. I. Kant, Uzasadnienie metafizyki, op. cit., s. 42 i 64.

${ }^{79} \mathrm{Idem}$, Metafizyczne podstawy nauki, op. cit., s. 54 i n.

${ }^{80}$ Ibidem, s. 127 i n.

${ }^{81}$ Ibidem, s. 128.

${ }^{82}$ Por. Cz. Znamierowski, Sprawiedliwość, „Państwo i Prawo” 1957, z. 4-5, s. 699-705; idem, Rozważania wstępne do nauki, op. cit., s. 227-239.

${ }^{83}$ Ibidem, s. 705.

${ }^{84}$ Ibidem, s. 701.

${ }^{85}$ Por. ibidem, s. 705.

${ }^{86}$ Ibidem, s. 705.

${ }^{87}$ Por. idem, Szkoła prawa, op. cit., s. 379 oraz 500; zob. także pracę doktorską napisaną przez Annę Kryniecką-Piotrak pod kierunkiem Marii Szyszkowskiej pt. Koncepcja demokracji w pogladach filozoficznych Czesława Znamierowskiego, obronioną na Wydziale Prawa i Administracji UW w 2003 r. 
powszechną, a więc dążyć do tego, by wszyscy mieli równą moc stanowienia o prawach $\mathrm{w}$ państwie i byli równi w swoich uprawnieniach ${ }^{88}$. Niemniej jednak w państwie demokratycznym, w którym naczelnymi wartościami są wolność, równość i braterstwo, sprawować władzę powinni najlepsi, którzy kierują się życzliwością powszechną, dbając przede wszystkim o dobro i szczęście innych ludzi ${ }^{89}$.

\section{5. Życzliwość powszechna a filozofia praktyczna Immanuela Kanta}

Porównując koncepcję życzliwości powszechnej Cz. Znamierowskiego z kantowskim imperatywem kategorycznym, należy zauważyć, iż obie zasady etyczne mają charakter nakazów powszechnych, stanowiących przy tym fundament właściwego postępowania moralnego. Życzliwość powszechna w filozofii Kanta nie mogła być jednak maksymą moralną ${ }^{90}$, gdyż był nią tylko imperatyw kategoryczny. Kierujący się życzliwością wobec innych ludzi postępuje zgodnie $\mathrm{z}$ nakazem imperatywu praktycznego, nakazującego traktować każdego człowieka jako „cel sam w sobie”. Życzliwość powszechna jest „powszechna, bo daje wskazanie, jak czuć i jak czynić ma człowiek we

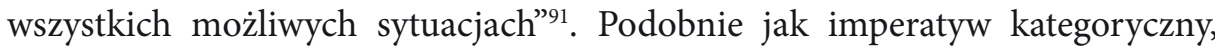
stanowi ona jedyną podstawową normę moralną, z której wysnuwa się normy szczegółowe o mniejszym zasięgu. Zalążki życzliwości powszechnej, zakłada się milcząco, że są w każdym człowieku. „Może on je rozwinąć w pełni i uczynić ważkim składnikiem swej konstelacji uczuć"' ${ }^{2}$. Dzięki niej człowiek może zdać sobie sprawę z tego, „że się zwraca ku każdemu człowiekowi, że ceni istnienie wszystkich ludzi na równi, że pragnie największego przydziału szczęścia dla każdego z nich, że wreszcie gotowa jest czynem i wysiłkiem własnym poprzeć i zrealizować to pragnienie" ${ }^{\prime 3}$.

${ }^{88}$ Por. M. Szyszkowska, Europejska filozofia, op. cit., s. 146.

${ }^{89} \mathrm{Cz}$. Znamierowski wyróżniał kilka rodzajów elit społecznych: elitę walorów, elitę rodową, elitę funkcji, elitę zasług, elitę pasożytniczą, elitę godności i elitę rycerską. Tej ostatniej „przypisywał najważniejszą rolę w budowaniu sytemu demokratycznego i wszelkiego postępu społecznego”. Por. Cz. Znamierowski, Elita i demokracja, [w:] Elita, ustrój, demokracja, op. cit., s. 27 i n.; zob. I. Jackiewicz, Przedmowa, [w:] ibidem, s. 9; A. Kryniecka, Czesława Znamierowskiego koncepcja demokracji w związku z przełomem wieków, [w:] Przełomy wieków, M. Szyszkowska (red.), Białystok 2000, s. 190 i n.

${ }^{90}$ Por. I. Kant, Krytyka praktycznego, op. cit., s. 136.

${ }^{91} \mathrm{Cz}$. Znamierowski, Zasady i kierunki, op. cit., s. 61-62.

${ }^{92}$ Idem, Naczelna norma moralna i jej pochodne, „Studia Filozoficzne” 1957, nr 3, s. 97.

${ }^{93}$ Idem, Rozważania wstępne do nauki, op. cit., s. 32-33. 
Z faktu narodzin i życia człowieka wśród ludzi wynika, iż jest on istotą społeczną i towarzyską, która potrzebuje więzi społecznej, a więc innych ludzi, by móc okazywać im życzliwośś ${ }^{94}$. W tym celu tworzy rozmaite zbiorowości, których członków łączy nie tylko wspólny cel, ale także kultura i cywilizacja oraz inne więzy, czy związki społeczne, nazywane ludem, plemieniem, narodem, a na wyższych szczeblach rozwoju - społeczeństwem, czy państwem ${ }^{95}$. Związki społeczne mogą być przy tym naturalne, jeśli powstają przez naturalną grę sił przyrodzonych oraz stanowione, gdy powstają na mocy decyzji ${ }^{96}$. Szczególna rola, jaką Cz. Znamierowski przypisuje tutaj rozwojowi kultury i cywilizacji, odpowiada założeniom filozofii kantowskiej, zgodnie z którą rozwój i postęp ludzkości jest celem samej przyrody i jej przeznaczeniem ${ }^{97}$. Według Kanta postęp moralny jest taką samą koniecznością w procesie dziejowym jak rozwój kultury i cywilizacji.

\section{Wartość pokoju w poglądach Czesława Znamierowskiego}

Cz. Znamierowski zgadzał się z Kantem w kwestii wojny, uważając ją za zło i „największe nieszczęście spadające na ucywilizowane narody” ${ }^{8}$, ponieważ „trzeźwo biorąc, wojna nigdy nie opłacała się nawet zwycięzcom. Ta następna zaś byłaby po prostu sądem nad ludzkością. Od tej wojny właśnie mają bronić humaniści wylękłych przyrodników, no i ludzkość całą. To jest główna, najpilniejsza potrzeba chwili. Za nią stoi najbardziej ogólna potrzeba człowieka: pragnienie szczęścia i ucieczka przed cierpieniem"99. Znamierowski, inaczej niż Kant, uznał za swój obowiązek jako uczonego troskę o szczęście jednostek, która dla królewieckiego filozofa była sprawą indywidualną ${ }^{100}$. Postawa pacyfistyczna Znamierowskiego związana jest głównie z życzliwością powszechną, która skłania do bezwzględnego poszanowania ludzkiego życia, a także nie krzywdzenia i nie zadawania cierpień innym ${ }^{101}$. Nieodzowna dla ustanowienia pokoju

${ }^{94}$ Por. idem, Zbiorowość. Naród. Państwo, „Ruch Prawniczy, Ekonomiczny i Socjologiczny” 1965, z. 1, s. 265 i n.

${ }^{95}$ Zob. idem, O przedmiocie i fakcie społecznym, „Przegląd Filozoficzny” 1921, nr 1, s. 1-33; idem, Zespół osób, „Przegląd Socjologiczny” 1946, t. 8, s. 141-171.

${ }^{96}$ Idem, Szkoła prawa, op. cit., s. 7 i n.

${ }_{97}$ Por. E. Wolicka, Rozważania wokót Kanta. Prolegomena do filozofii kultury jako krytyki władz podmiotu, Lublin 2002, s. 208 i n.

${ }^{98}$ I. Kant, Wznowione pytanie czy rodzaj ludzki stale zmierza ku temu, co lepsze?, op. cit., s. 191; idem, Przypuszczalny początek ludzkiej historii, op. cit., s. 31.

${ }^{99}$ Cz. Znamierowski, Potrzeby życia a nauki społeczne, „Życie Nauki” 1947, t. 3, nr 17-18, s. 290.

${ }^{100}$ Por. M. Szyszkowska, Europejska filozofia, op. cit., s. 148.

${ }^{101}$ Por. A. Kryniecka-Piotrak, Kantowskie inspiracje w poglądach pacyfistycznych Czesława Znamierowskiego, [w:] Filozofia Kanta w XXI wieku, op. cit., s. 165 i n. 
powinna być etyka jako nauka o postępowaniu, kierowanym normami. Tak rozumiana etyka może wykazać, „że normy społeczne powstają w obcowaniu pokojowym ludzi, że podtrzymują i utrwalają równowagę społeczną, a więc pokój. I może dowieść, nie zniżając się do nędznego fałszowania faktów, że normy moralne, dyktowane przez życzliwość powszechną, stanowią najbardziej niezawodną bazę pokoju; albowiem pokój, jak to już mówi Ewangelia, jest błogosławieństwem, które spływa tylko na ludzi dobrej woli”'102. Jak podkreśla Anna Kryniecka-Piotrak, w człowieku znajdują się, zdaniem Kanta, skłonności zagrażające ludzkiej egzystencji $\mathrm{w}$ pokoju, a mianowicie potrzeba władania i chęć posiadania ${ }^{103}$. Ludzie, podejmując działania zaczepne, dają wyraz swojej drapieżności i ulegają złudzeniu, że pomnożą swoje dobra bez krzywdzenia innych ${ }^{104}$. Aby temu zapobiec, Cz. Znamierowski, podobnie jak Kant, uważał, że jedynymi możliwymi granicami działania członków zbiorowości powinny być trwałe i niezmienne normy postępowania, stanowiąc tym samym ochronę przed nieoczekiwanymi reakcjami innych ludzi ${ }^{105}$. $\mathrm{Z}$ kolei gwarantowane przez nie bezpieczeństwo równoważyłoby ewentualne niedogodności, wynikające $\mathrm{z}$ istnienia niedoskonałości i niesprawiedliwości ${ }^{106}$.

\section{Elementy etyki deontologicznej w poglądach Czesława Znamierowskiego}

Poglądy filozoficznoprawne Znamierowskiego wiążą się z etyką. Według niego etyka nie jest jednak nauką o postępowaniu, lecz nauką „o praktyce życiowej w ogóle, a więc również i o tym, jak powstają nasze oceny i jak z nich wywodzą się normy" ${ }^{107}$. Ocena moralna według Cz. Znamierowskiego nie patrzy więc, podobnie jak twierdził Kant, na zewnętrzne zachowania człowieka, lecz na jego wnętrze - sięgając w głąb jego świadomości ${ }^{108}$. Życzliwość powszechną Znamierowski utożsamiał z sumieniem ${ }^{109}$. Pełni ono istotną funkcję $\mathrm{w}$ świadomości człowieka, czuwając stale nad tym, co on przeżywa i ceni ${ }^{110}$. Z kolei dla

${ }^{102}$ Cz. Znamierowski, Potrzeby życia, op. cit., s. 300.

${ }^{103}$ A. Kryniecka-Piotrak, Pacyfizm w pogladach Czesława Znamierowskiego, [w:] Pacyfizm. Prawo a dzieje państwa i ustroju, t. 2, M. Szyszkowska (red.), Białystok 2001, s. 70.

${ }_{104}$ Por. Cz. Znamierowski, Oceny, op. cit., s. 325.

${ }^{105}$ Por. A. Kryniecka-Piotrak, Pacyfizm w pogladach, op. cit. 71.

${ }^{106}$ Por. Cz. Znamierowski, Oceny, op. cit., s. 325.

${ }^{107}$ Idem, Zasady i kierunki, op. cit., s. 71.

${ }^{108}$ Ibidem, s. 59.

${ }^{109}$ Idem, Rozważania wstępne do nauki, op. cit., s. 37.

${ }^{110}$ Oceny, op. cit., s. 411 i n. 
Kanta sumienie stanowi w człowieku świadomość wewnętrznego „trybunału”, osądzającego samego siebie, a nie to, czy jakieś postępowanie jest słuszne bądź niesłuszne, ponieważ to rozstrzygać ma rozum ${ }^{111}$. Kantowska teoria sumienia wspiera się na pozornie paradoksalnym rozróżnieniu pomiędzy moralnym sądem i aktem sumienia ${ }^{112}$. A zatem „sumienie jest praktycznym rozumem, który za każdym razem, gdy znajduje się w zasięgu pewnej normy, stawia nam przed oczyma obowiązek, abyśmy wydali [w stosunku do siebie] wyrok uniewinniający albo skazujący"113.

$\mathrm{Na}$ tej podstawie można również powiedzieć, że szczególne znaczenie w ocenie moralnej danego czynu obaj myśliciele przypisywali powinności. To, co być powinno, nie jest spełnioną rzeczywistością. Skłania, by dążyć do określonego stanu, który być może. „Poczucie jest pędem wewnętrznym ku wykonaniu jakiegośdziałania; jest naciskiem, jaki wywiera ten pęd na świadomość” ${ }^{114}$. Norma prawna swoje poczucie powinności, które rodzi się z dążenia do określonego celu, wzmacnia i utrwala w świadomości ${ }^{115}$. „Gdy poczucie powinności oparte jest na ocenie, wskazuje ogólnie, że należy czynić to a to, ilekroć powstanie pewien splot warunków, to wówczas również decyzja może doprowadzić do gotowości działania"116. Taką decyzję nazwiemy wówczas stanowieniem normy, o czym była już mowa. Powinność stanowi bowiem takie poczucie, które ma pewną siłę motywacyjną, zwaną inaczej "sugestyjnością normy”, decydującą o mocy obowiązującej normy, zgodnie z którą będziemy postępować ${ }^{117}$. W poczuciu powinności zawiera się także poczucie konieczności, ponieważ z normą, która narzuca nam określoną powinność $\mathrm{w}$ danej sytuacji, wiąże się tylko jeden stan rzeczy, co koliduje $\mathrm{z}$ głęboko zakorzenionym dążeniem do swobody ${ }^{118}$. Kant twierdził, że jedynie człowiek wolny jest $\mathrm{w}$ stanie postąpić $\mathrm{z}$ obowiązku, w przeciwieństwie do tych, którzy nie są wolni, choć mogą postępować zgodnie z obowiązkiem, ale bez jego poczucia, które okazuje się najważniejsze.

W przeciwieństwie do Kanta, Znamierowski ujmował powinność jako przeświadczenie, mające charakter uczuciowy, a nie rozumowy. Etyczne stanowisko królewieckiego filozofa nazwał on racjonalizmem etycznym, czyli poglądem według którego szczególną rolę przypisuje się rozumowi wskazującemu

${ }^{111}$ Por. I. Kant, Metafizyczne podstawy nauki, op. cit., s. 110.

${ }^{112}$ Por. W. H. Schrader, Teorie sumienia, tłum. E. Nowak-Juchacz, [w:] Transcendentalna filozofia praktyczna, E. Nowak-Juchacz (red.), Poznań 2000, s. 150.

${ }^{113}$ I. Kant, Metafizyczne podstawy nauki, op. cit., s. 69.

${ }^{114}$ Cz. Znamierowski, Oceny, op. cit., s. 474.

${ }^{115}$ Por. idem, $Z$ abecadła, op. cit., s. 125 i n.

${ }^{116}$ Ibidem, s. 118.

${ }^{117}$ Idem, Rozważania wstępne do nauki, op. cit., s. 24.

${ }^{118}$ Por. ibidem, s. 26-27. 
„człowiekowi jedyne ogólneiformalneprawo moralne, które nakazujepostępować tak, by reguła naszego zachowania mogła być normą powszechną"119. Jedynie postępując według prawa moralnego, „osiągniemy wolność wewnętrzną, a z tym i doskonałość moralną, która polega na tym, że człowiek staje się doskonałym narzędziem rozumu i osiąga dostojeństwo moralne, które winno być celem dla każdego człowieka"120. Rozum teoretyczny nie jest w stanie uczynić więcej niż ustalić, co istnieje, a nie co być powinno. Dlatego też nie rozum teoretyczny, a rozum praktyczny wskazuje obowiązek moralny u Kanta. Zdaniem Cz.Znamierowskiego, Kant nie wskazał jednak, jakie są swoiste zdolności rozumu praktycznego, dzięki którym może on sam, bez udziału wzruszeń i dążeń, oceniać i wskazywać właśnie to, co być powinno. „Sama myśl poznawcza nie umie nic oceniać, choćbyśmy ją nazwali rozumem praktycznym; bez dążeń nie ma bowiem powinności" ${ }^{121}$. Kant nie wyjaśnił genezy prawa moralnego, któremu poddać się jest naszym obowiązkiem. Twierdził, że ludzie, jako istoty rozumne, dysponują władzą oceniania, określaną przez niego zdolnością wydawania sądów, czy też władzą sadzenia. Ta zaś musi być a priori prawodawcza ${ }^{122}$.

\section{Wnioski}

Oceniając kantowską etykę, Cz. Znamierowski stwierdził, że Kant w wielu sprawach miał sąd słuszny i humanitarny. „Z mocnym naciskiem podkreślał dostojeństwo jednostki, która nigdy nie może być środkiem; cenił wysoko wolność osobistą, był przeciwnikiem wojny i rzecznikiem wiecznego pokoju, ale znów tym, że z przeżyć moralnych usunąć chciał wszelkie miękkie poruszenia serca, wszelkie motywy, płynące z uczuć, zmroził duszę swych ziomków i przyczynił się, że w jego narodzie tak się umocniła tresura posłuszeństwa. Jego podstawowa maksyma tak łatwo da się związać z życzliwością powszechną, bo przecież kto równego chce dla wszystkich dobra, ten chce też, by jego norma była normą dla wszystkich"123.

Podejście Cz. Znamierowskiego do kantowskiej filozofii uwarunkowane jest jego negatywnym stosunkiem do idealistycznej filozofii niemieckiej. Znamierowski zdawał sobie sprawę, iż filozofia kantowska wywierała znaczący

\footnotetext{
${ }^{119}$ Idem, Zasady i kierunki, op. cit., s. 103.

${ }^{120}$ Ibidem, s. 103-104.

${ }^{121}$ Ibidem, s. 105.

122 Por. I. Kant, Krytyka czystego rozumu, tłum. R. Ingarden, t. 1, Warszawa 1986, s. 280-282; idem, Krytyka władzy sądzenia, tłum. J. Gałecki, Warszawa 1964, s. 19 i n., 23 i n. oraz 53-55.

${ }^{123} \mathrm{Cz}$. Znamierowski, Zasady i kierunki, op. cit., s. 106.
} 
wpływ na kolejne pokolenia europejskich filozofów prawa ${ }^{124}$. Chociaż nie można powiedzieć, że idealistyczna filozofia Kanta była aprobowana przez Cz. Znamierowskiego, to jednak można dostrzec wyraźne podobieństwa i liczne nawiązania do jej praktycznych rozwiązań. Czesław Znamierowski czerpał z filozofii Kanta, przede wszystkim krytycyzm, jako sposób myślenia, który okazał się znakomitą podstawą do budowania własnego stanowiska zarówno filozoficznego, jak i teoretycznoprawnego.

${ }^{124}$ Zob. A. Mycielski, Kant jako inspirator w europejskiej filozofii prawa, „Znak” 1974, nr 6, s. 805-810 . 